\title{
A Study on the Attitude of Secondary Level Students Towards E-Learning During COVID 19 Pandemic With Reference To Dibrugarh District, Assam
}

\section{Swapna Sikha Das}

Research Scholar, Department of Education, Tezpur University, Napaam, Assam, Pin-784028, Email:swapnasikhadas233@gmail.com

\section{Abstract}

The educational system has come across a kind of revolutionized process after the outbreak of COVID 19 pandemic with the emergence of fully E-learning system. The study objective is to examine the difference between male and female E-learning perspective in relation to their interest,usefulness, ease and comfort during COVID 19 pandemic. For the present study, the quantitative approach has been adopted and responses from 82 students of secondary level from Dibrugarh district are collected through standardized tool .The findings of the study reveal students' perception towards e-learning which is less satisfactory. Moreover the study have put forwards some recommendations for E-learning Success in the country and enhancing students' knowledge and skills through the internet.

\section{Backdrop of the study:}

Technology is now available for everyone and lot of people likes to use it as it provides any choice of information as per our need. Now with the help of technology E learning has emerged as a mode of learning that takes place in an electrical mode through video, e books, online practices etc. and provides unlimited learning. This learning method helps in grasping different knowledge in a much more interesting way. E learners have access to a vast pool of knowledge. Thus E-learning today is a very important.

The process of $\mathrm{E}$ learning empowers one to accomplish his/her goal due to active engagement in learning online. It is now considered as a pathway to opportunities. The e-learning leads to indepth learning, productivity, student satisfaction, encouragement and pace of learning. Long Pham, Limbu ,Bui,Nguyen,pham(2019) indicated the quality of e-learning system was the most important dimension of overall e- learning service that includes e-learning instructor and course materials, and e-learning administrative and support service quality. And there was positive co-relation with the overall elearning service quality and e-learning student satisfaction, which in turn positively influenced the e-learning student loyalty. E-learning helps become more digitized and makes contribution to the formation of a digital and knowledgeable society where learning and knowledge sharing can be conducted in a simple and fast way at anytime in anywhere with the help of Internet enabled technologies (Taylor, 2007;).

E-learning can take place anywhere through computer or other electronic devices connected to the Internet and the university's e-learning system (Bhuasiri et al., 2012; Kilburn, Kilburn, \& Cates, 2014).

The sudden outbreak of the virus Covid-19 shook the entire world on year 2020. It was declared as a Pandemic by the World Health Organization. 
Covid-19 has deeply affected the global economy .Moreover it is witnessed that this pandemic challenged the education sector across the world and forced educators, students to be out of the educational institutions. All over the world the educational institutions were closed down due to the outbreak of the virus and the total lockdown. Education have became a challenge and it becomes really important to save the students, teachers,institutions and the countries overall.

Thus with the raising situation e-learning was adopted across the countries. Teaching and learning was conducted on digital platforms. It has changed the way of learning. Students across the countries were reached by the teachers and schools more efficiently and effectively especially during this lockdown.

In India during Covid-19 pandemic and the lockdown, studying from home was the new normal. E-learning emerged as the biggest saviour leading to adoption of new online learning process.. However, there were challenges to overcome. Some students in rural parts of the country were far from reliable internet access. They faced challenges to learn online. This created a gap between the students and learning Many teachers were not familiar with the online process and thus leading to very challenging.Students who do not have smartphones, laptops, and the internet were difficult to reach out. Online classes for children with no facilities were of no use.

\section{Significance of the study:}

E-learning has started as a new paradigm in the education system that provides a holistic knowledge and enhance student academic development. The educational process by web has made it available anytime and anywhere. During this COVID-19 pandemic, education is delivered fully in E-learning process. With e-learning as sudden adoption, teachers as well as students are still in the process of adapting this new teaching and learning methodology. At this time of $\mathrm{E}$ learning and teaching as new normal in education; it's very important to know the opinion of students towards this new methodology. Student attitude towards E learning from the study would provide important information regarding their perception towards e learning so as to improve future learning strategies and its need for their academic development in such a time of crisis.. More researches are needed to know the attitude of the students in different parts of the country and particularly in Assam. It was with this back ground that a attempt was made to study the attitude of secondary level students towards eLearning during Pandemic of COVID 19 with reference to Dibrugarh district of Assam.

\section{Objectives of the Study}

1. To study the attitude of secondary level students towards e - learning during COVID-19 pandemic.

2. To study the comparative difference in attitude of secondary level students towards e- learning in relation to gender.

\section{Hypothesis of the Study}

1. There is no significant difference in attitude towards e- learning between male and female secondary level students.

\section{Design of the Study}

Research Methodology: the study is a quantitative research and Descriptive in nature.

\section{Population and Sample}

All the secondary level students of Dibrugarh district are the population of this study. A Sample of 82 students were randomly selected including both boys and girls of class 9 and 10 .

\section{Tool Used:}


Attitude Towards e-learning Scale developed by Dimpal Rani was used to collect the data for the study. The scale has four dimensions; 1. ELearning interest, 2. Usefulness, 3. Ease of elearning and 4. E-learning confidence. The scale is a five - point scale with 65 items. The responses are Strongly Agree, Agree, Undecided, Disagree and Strongly Disagree.

\section{Statistical Technique used:}

Graphs, Mean and t-test was used for the study.

\section{Analysis and interpretation:}

Objectives of the Study -

1.To study the attitude of secondary level students towards e -learning during Covid-19 pandemic.

Figure No1. Showing the Level of attitude of students on E-Learning

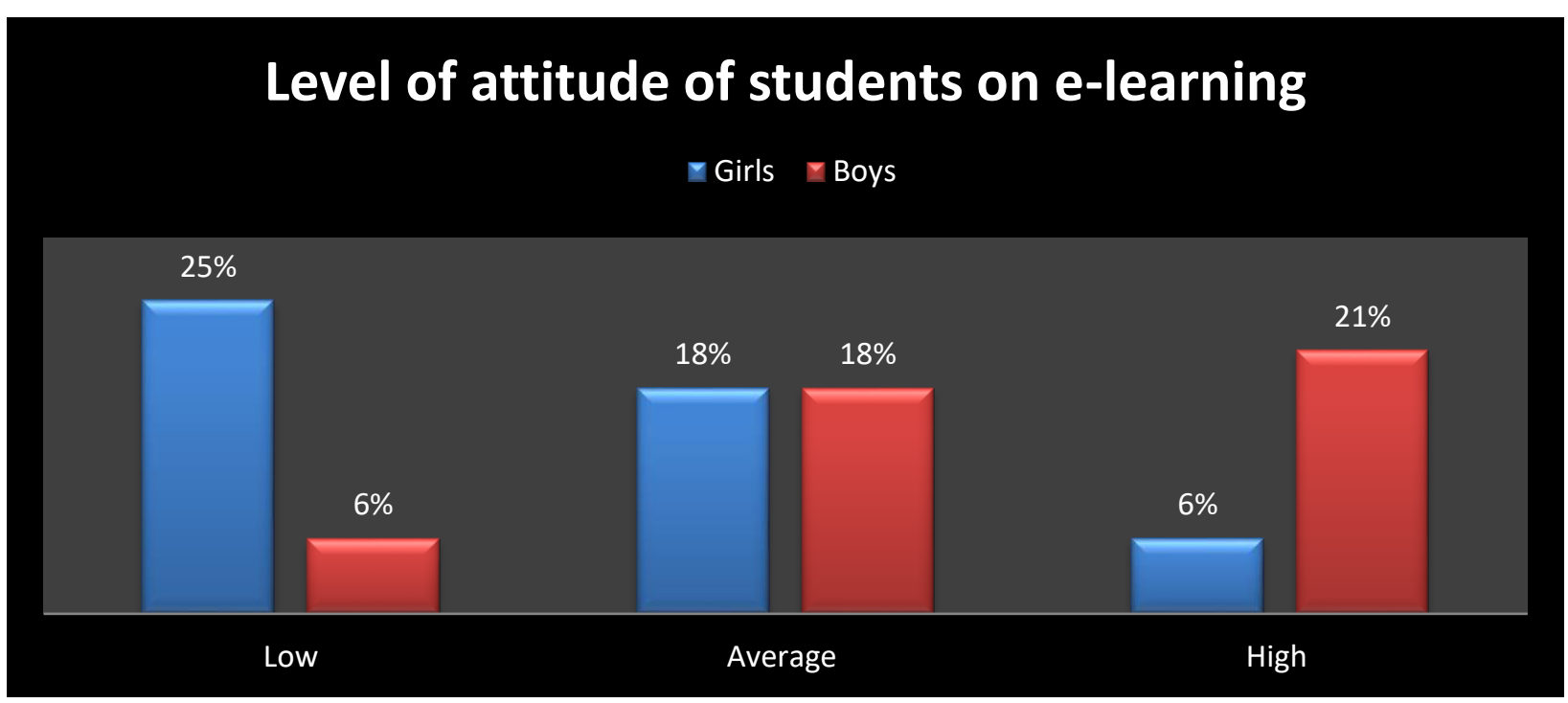

Objective 2. To study the comparative difference in attitude of secondary level students towards E- learning in relation to gender.

Table 1: Overall difference among male and female attitude towards E-Learning

\begin{tabular}{|c|c|c|c|c|c|}
\hline Gender & $\mathbf{N}$ & Mean & SD & t value & Significance \\
\hline Male & 41 & 170.09 & 7.98 & 4.93 & Not significant \\
\hline Female & 41 & 163.8 & 6.7 & & \\
\hline
\end{tabular}


Table 2: Difference among Male And Female Attitude Towards E-Learning Interest

\begin{tabular}{|l|l|l|l|l|l|}
\hline Gender & N & Mean & SD & t value & Significance \\
\hline Male & 41 & 35.56 & 3.77 & 2.27 & Not significant \\
\hline Female & 41 & & & & \\
& & 33.8 & 2.87 & & \\
\hline
\end{tabular}

Table 3: Difference among male and female attitude towards E-Learning Usefulness

\begin{tabular}{|c|c|c|c|c|c|}
\hline Gender & $\mathbf{N}$ & Mean & SD & t-value & Significance \\
\hline Male & 41 & 73.41 & 5.59 & 1.08 & $\begin{array}{l}\text { Not } \\
\text { Significant }\end{array}$ \\
\hline Feamle & 41 & 72.26 & 3.82 & & \\
\hline
\end{tabular}

Table 4: Difference among Male and Female Attitude Towards E-Learning Ease

\begin{tabular}{|l|l|l|l|l|l|}
\hline Gender & N & Mean & SD & t value & Significance \\
\hline Male & 41 & & 3.58 & 4.61 & significant \\
\cline { 1 - 5 } & & 34.93 & 3.36 & & \\
& & 41.24 & & & \\
\hline
\end{tabular}

Table 5: Difference among Male and Female Attitude Towards E-Learning Confidence

\begin{tabular}{|l|l|l|l|l|l|}
\hline Gender & N & Mean & SD & t-value & Significance \\
\hline Male & 41 & 27.02 & 4.13 & 0.75 & $\begin{array}{l}\text { Not } \\
\text { Significant }\end{array}$ \\
\cline { 1 - 5 } & & & & & \\
\hline
\end{tabular}

The findings reported in Figure 1 showed that $24 \%$ male have high level of attitude towards E-learning overall and only $6 \%$ female students have high attitude towards E-learning from secondary level school of Dibrugarh. So female are found to have low level of attitude 
towards E-learning with $25 \%$ in comparison to male students. And only $18 \%$ of both boys and girls have average level of attitude towards Elearning overall. It implies that students attitudes towards E-learning during COVID-19 Pandemic is not so satisfactory overall. This is may be due to the unfamiliarity with online learning process before COVID 19 pandemic happened and lack of exposure to the digital learning world. Overall the level of attitude is found to be less satisfactory. Due to lack of proper awareness and poor internet services the female students are not able to advance in E- learning aspects. This may be due to the lack of access to gadgets and basic digital devices that has deprived them of online education. According to The Mobile Gender Gap Report 2020 of Groupe Speciale Mobile Association (GSMA) that represents the interests of mobile operators worldwide, only half of the women in India use mobile internet compared to men-21\% among of women compared to $42 \%$ of men(Banerjee 2020).

In the results of the present study, from Table 1 showed the mean difference of male and female student attitude towards E-learning overall. It is observed from the study that there is a difference between the mean score of both male and female. The mean score of the male is 170.9 and the mean score of the girls is 163.8. And the t-value calculated is found to be 4.361. Thus the hypothesis set is rejected showing "There is significant difference in attitude towards Elearning between male and female secondary level students."

Table 2 showed the mean difference of male and female student attitude towards E-learning interest. It is observed from the study that there is a difference between the mean score of both male and female. The mean score of the male is 35.56 and the mean score of the girls is 33.8. And the tvalue calculated is found to be 2.27 . Thus the hypothesis is accepted showing "There is no significant difference in attitude towards Elearning between male and female secondary level students"in regards to interest.

Table 3 showed the mean difference of male and female student attitude towards E-learning usefulness . It is observed from the study that there is a slight difference between the mean score of both male and female. The mean score of the male is 73.41 and the mean score of the girls is 72.27. And the t-value calculated is found to be 1.08. Thus the hypothesis is accepted showing "There is no significant difference in attitude towards E- learning between male and female secondary level students" in regards to usefulness.

Table 4 showed the mean difference of male and female student attitude towards E-learning ease . It is observed from the study that there is a difference between the mean score of both male and female. The mean score of the male is 34.93and the mean score of the girls is 31.24. And the t-value calculated is found to be 4.61 , thus significant at both level of significance. So the hypothesis is rejected showing "There is significant difference in attitude towards elearning between male and female secondary level students" in regards to E-learning ease. And the result may be because boys are much more likely than the females to use internet and have familiarity E-learning process.

Table 5 showed the mean difference of male and female student attitude towards E-learning comfort . It is observed from the study that there is a slight difference between the mean score of both male and female. The mean score of the male is 27.02 and the mean score of the girls is 26.44 . And the t-value calculated is found to be 0.75 . Thus the hypothesis is accepted showing "There is no significant difference in attitude towards Elearning between male and female secondary level students" in regards to E-learning comfort. 


\section{Findings :}

From the results it is found male students shows high attitude towards E-learning than their counterpart overall.

There is significant difference between the attitude of male and female students towards Elearning overall.

There is no significant difference between the attitude of male and female students towards Elearning interest.

There is no significant difference between the attitude of male and female students towards Elearning usefulness.

There is significant difference between the attitude of male and female students towards Elearning ease.

There is no significant difference between the attitude of male and female students towards Elearning comfort.

\section{Conclusion:}

From the results it is indicated that both male and female students should be equally more involved in the use E-learning strategy so as to enhance their learning. Female students should be more involved in the use E-learning strategy so as to enhance their learning and have ease towards E learning. Overall male have wider attitude and knowledge than females, so females need more information about $\mathrm{E}$ learning use. The reasons may be stress, economic problem, changes in daily life, discrimination against girls as they are expected to do household works instead of attending online classes from hours to hours. This disparity appears to have adverse effect during the COVID-19 pandemic. And boys are advantage of the anywhere, anytime convenience of online learning. Most of the male students are found to be comfortable and confident with the use of Elearning.
As COVID 19 pandemic has forced global closure thus pushing all the institutions to online platform,E-learning has become compulsory to all educational institutions like schools, colleges, and universities in and around the world due to the pandemic crisis of COVID-19. Before COVID-19 pandemic, learning was classroom based. As the COVID-19 pandemic guidelines forced the studies from home lectures and assessments were carried out using various online platforms like Zoom meetings, PPTs etc. and it affected millions of students to a large extent. Many students have felt less learning satisfaction and more difficulty in communicating with teachers or with classmates. In many studies challenges of student readiness to learning,no electronic devices,network error, time management and difficulty to stay focused for long online learning duration were reported. The COVID 19 pandemic has through light on the ever-increasing structural imbalances in school education in terms of ruralurban, rich and poor and gender divide(Singh,2020).

\section{Recommendations :}

a. Education should be made accessible through more technology aids for making education effective

b. Effective Government policies are the need of the hour to bridge this gap between gender and rich and poor.

c. To spread literacy and to build a knowledgeful society a powerful digital platform is needed to develop.

d. More researches and studies should be conducted in this area to know about the prevailing conditions and the need to make more

e. Training should be given to teachers, parents and other people of the communities on electronic access to facilitate online learning and support learners in the learning platform. 


\section{Bibiliography:}

[1]. Banerjee, S. (2020, December 25). Girls and boys need equal tech access for online school classes.

https://www.hindustantimes.com/analysis/girlsand-boys-need-equal-tech-access-for-online-

school-classes/storyyB0qwTMIYT9yTf8gpRqLbM.html.

[2].elearn Magazine: Where the Boys Are: Understanding online learning and gender. eLearn Magazine, an ACM Publication. https://elearnmag.acm.org/featured.cfm?aid=26 62455.

[3]. Garcíaa,C.M.; Molinaa ,E.M, MontoroPonsb,D.J.(2010). Are there gender differences in e-learning use and assessment? Evidence from an interuniversity online project in Europe . Procedia Social and Behavioral Sciences 2,367-

371.https://core.ac.uk/download/pdf/82441812. pdf

[4]. Kar,D. Saha, B.Bhim ,\&Mondal,C.(2014). Attitude of University Students towards Elearning in West Bengal . American Journal of Educational Research 2( 8), 669-673

[5]. Kayalar, M. (2018). EXAMINING PRESERVICE TEACHERS' ATTITUDES AND
INTERESTS IN TECHNOLOGY IN TERMS OF VARIOUS VARIABLES. International Journal of Social Humanities Sciences Research (JSHSR), 5(27), 2753-2760. https://doi.org/10.26450/jshsr.671

[6]. Kisanga,H.D.(2016). Determinants of Teachers' Attitudes Towards E-Learning in Tanzanian Higher Learning Institutions. International Review of Research in Open and Distributed Learning 17( 5)

[7]. Ramírez-Correa, P. E., Arenas-Gaitán, J., \& Rondán-Cataluña, F. J. (2015, October 14). Genderand Acceptance of E-Learning: A Multi-Group Analysis Based on a Structural Equation Model among College Students in Chile and Spain. https://www.ncbi.nlm.nih.gov/pmc/articles/PM C4605762/.

[8]. Taylor, P. S. (2007). Can clickers cure crowded classes? Maclean's, 120(26-27), 73.

[9]. Pham, Limbu,Bui,et al.( 2019). Does elearning service quality influence e-learning student satisfaction and loyalty? Evidence from Vietnam.International Journal of Educational Technology in Higher Education, 16(7) 